\title{
How many case studies should we publish, if any?
}

\author{
Walter Klöpffer • Mary Ann Curran
}

Received: 17 October 2013 / Accepted: 23 October 2013 /Published online: 13 November 2013

(C) Springer-Verlag Berlin Heidelberg 2013

\section{Dear Readers,}

From the beginning, it has been the editorial policy of this journal that academic as well as applied life cycle assessment (LCA) studies be published (Klöpffer 1996). This concept has been very successful (as seen in the Journal's increasing impact factor) and will not be changed in principle (Klöpffer et al. 2013), at least not in the foreseeable future. Papers based on academic studies, of course, contribute to the advancement of knowledge in LCA methodology. Papers based on applied LCA studies also bring value by covering a wide range of practical issues, from the application and testing of the methods developed in the academic field, to the application of established methods to specific product systems in "case studies." It is this last point which is sometimes criticized as boring or lacking new information. Reinout Heijungs provided his thoughts on journals that publish papers that do not address methods and techniques, but merely employ them:

I compare the situation with the (hypothetical) Journal of Statistics. In it, you will find articles like "A new maximum likelihood estimator for removing bias in stratified samples", but not "A statistical analysis of tomato cultivation". So, I expect (to find) in IntJLCA articles like "Improved characterization factors for metal speciation", but not "An LCA of granite production". Even not when it has new data, after all, the Journal of Statistics doesn't publish new data on tomato yield either (Heijungs 2013).

\footnotetext{
W. Klöpffer

LCA Consult \& Review, Am Dachsberg 56E, 60435 Frankfurt am Main, Germany

M. A. Curran ( $\square)$

LCA \& Sustainability Consultant, 5137 Oak Book Drive, Cincinnati, OH 45244, USA

e-mail: macurran@cinci.rr.com
}

Although we think this criticism is exaggerated, we agree that a certain standard is required in order to reflect the growing sophistication of LCA practice as it evolves.

An editorial written by our esteemed colleague and editorin-chief of the Journal of Industrial Ecology, Reid Lifset, deals with the same question of publishing case studies (Lifset 2013). He identifies criteria which should be met by manuscripts submitted to his journal in the fields of LCA and material flow analysis. They must:

- Bring new data into the literature (including the provision of substantial raw, documented, or important data)

- Employ a novel methodology, or

- Shed light on a specific topic or problem of interest or significance

The first bullet addresses the constant quest of LCA practitioners to identify and acquire reliable life cycle inventory data and impact data. The widespread use of data-containing LCA software has taken the performance of an LCA from a rarity to an almost commonplace and routine event. With increasingly easy access of generic data provided by modern LCA software and databases, often no new data are communicated in case studies, not even for foreground processes. Reid's second criterion regarding novel technology complements the aim of typical case studies, with which we agree. The third one is fully to the point: even modest submissions should bring something new and relevant to the field of LCA or similar product-related assessment. In addition, a new application can be the first attempt to apply a life cycle study within a country not yet fully indoctrinated in life cycle thinking. These opportunities are highly valued by the organizers of the UNEP/SETAC life cycle initiative who view them with great interest as the basis for developing regional capacity and promoting the use of life cycle thinking throughout the world (UNEP/SETAC 2013).

There will always be a place for case studies, but, like our colleagues at $J$ Ind Ecol, we see the emphasis shifting 
to those that effectively test current claims or expand life cycle thinking into new areas. We propose adopting similar criteria for the Int J Life Cycle Assess in refining the editorial policy for accepting papers on applied LCAs. We suggest that in the future, our submission editors and reviewers look for how a paper on applied LCA, especially case studies, offers new knowledge and new insight. If not present, the manuscript should not be accepted for peer review. Alternatively, authors can be asked to submit a revision (new paper) highlighting or adding novel information and new knowledge added. Before adding these requirements to the current editorial policy, we would like to hear the opinions of our subject and regional editors, members of the editorial board, authors, and readers. Please comment by email or by a "letter to the editors."

\section{References}

Heijungs R (2013) private communication by email

Klöpffer W (1996) Untitled editorial (distributed in December 1995). Int J Life Cycle Assess 1(1):3

Klöpffer W, Curran MA, Roos P (2013) Two captains on the bridge. Editorial. Int J Life Cycle Assess 18(3):535-537

Lifset R (2013) Raising the bar for symbiosis, life cycle assessment, and material flow analysis case studies. Editorial. J Ind Ecol 17(1):1

UNEP/SETAC (2013) Life Cycle Initiative website. Global Capability Development: http://www.lifecycleinitiative.org/activities/phase-iii/ global-capability-development/ Accessed 15 October 2013 